\title{
Promoting Personal Learning Environment (PLE) for Emerging Academic Writing for Publication for Higher Education Students
}

\author{
Nur Arifah Drajati, ${ }^{*} A^{\prime}$ thi Fauzani Wisudawati, ${ }^{2}$ Anis Handayani ${ }^{3}$ \\ 1,2,3 Universitas Sebelas Maret, Surakarta - Indonesia \\ ${ }^{*}$ Corresponding Author \\ Email: nurarifah_drajati@staff.uns.ac.id \\ DOI: 10.18326/rgt.v13i2.293-314
}

Submission Track:

Received: 30-05-2020

Final Revision: 13-10-2020

Available Online: 01-12-2020

Copyright @ 2020 Nur Arifah Drajati, A'thi Fauzani Wisudawati, Anis Handayani

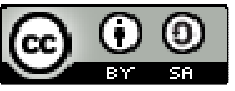

This work is licensed under a Creative Commons Attribution-ShareAlike 4.0

International License.

\begin{abstract}
Academic writing for publication in higher education is cognitively and linguistically complex. University students grapple with academic writing for publication because of academic genre/convention, linguistic competence, and academic literacy among others. For those reasons, a learning environment does matter. The Personal Learning Environment (PLE) is a learner-controlled environment for language learning. To examine this issue, a qualitative study with an action research design was conducted with 28 graduate students as participants by conducting three points: (1) ways of encouraging students to write academic writing for publication through the personal learning environment as a learning platform; (2) implementing PLEs in the academic writing for publication course: content knowledge consideration; and (3) implementing PLEs in the academic writing for publication course: pedagogical consideration. In general, the findings indicated that promoting PLE gives more space for the students to develop their potential and ability on academic writing matters in the context of higher education as they have plenty of time, space and sources. This study implies that the educational organization needs to consider this issue.
\end{abstract}

Keywords: academic writing for publication; learning autonomy; personal learning environment 


\section{INTRODUCTION}

The emergence of tools and resources significantly supports the holistic process of the personal learning environment (Attwell, 2007; Attwell \& Costa, 2009; Bimrose \& Brown, 2008; Dabbagh \& Kitsantas, 2012; Lebbenicnik, Pitt, \& Starcic, 2015; Harmelen, 2008; Reinders, 2014). The idea of PLE always collaborates with tools as learning support (Attwell \& Hughes, 2010). PLEs combine tools and resources that help learners take control into their languagelearning process. Both tools and resources are usually chosen and managed by learners themselves and can be quickly taken and used from a computer or a smartphone (Reinders, 2014), although another statement by Dabbagh \& Kitsantas (2012) suggests that PLE can still work as well without the aid of technology. However, most experts view that technology is very significant in the learning environment.

Driven by economic globalization, higher education institutions have been adopting a publish-or-perish system. It is undeniable that both individuals and universities gain reputation and research funds (Hyland, 2016). It is also believed that writing for publication is rewarding through citations, which is for measuring the productivity of the students and lecturers, in the university (Wells \& Soderlund, 2018). In recent years, academic writing for higher education students means writing for publication. It is a must for master and doctorate students to produce academic writing for publication. This phenomenon also dominates students across the world with 1.5 million peerreviewed articles each year (Bjork, Roos, \& Lauri, 2009).

Writing for publication gives a load for higher education students both cognitively and linguistically (Zhang \& Hyland, 2018). Students should grapple with difficulties in academic genre/convention, linguistic competence, and academic literacy, thus it leads the students in the 'shocked' situation (Wang \& Kai-Hui, 2018). The undergraduate students in the UK make efforts in classifying, choosing and employing academic reading to their writing tasks (Elliot \& Squire, 2017). Not only in Europe, but also in Indonesia, the students have a lack of knowledge and critical thinking skills in writing an argumentative essay (Niamika \& Widiati, 2017; Widyastuti, 2018). Students get difficulties in 
differentiating the claims, finding evidence, utilizing warrant and acknowledgment in writing their argumentative essay (Pirttimaa, Takala \& Ladonlahti, 2015).

An array of research studies on academic writing for publication for higher education has been undertaken to examine various features, such as writing and publication (Kutieva \& Mauranen, 2014; Nygaard, 2017; Salager-Meyer, 2014; Yayli \& Canarajah, 2018). Efforts in supporting students for writing for publication can take the form of selecting related topics of research, reading articles in past issues of the reputable journals, and looking for assistance from supervisors (Cheung, 2010). Moreover, there is a writing transition from high school to university demands (Foster \& Russell, 2017). Students need support in writing activities as part of language learning from their environments, such as motivation from inside and outside the classroom (Peng \& Woodrow, 2010). However, very few studies have been conducted to investigate and promote a personal learning environment in assisting students because it is considered to be a new concept in education (Liew \& Kang, 2012). Thus, the present study attempted to fill this gap. Anchored in the PLE theory, this study attempted to promote the personal learning environment to emerging academic writing for publication as part of the Indonesian higher education policy.

\section{Personal Learning Environment (PLE)}

The term personal learning environment is initially built up from constructivism theory, which is believed to be the underlying principle that a learner can develop his/her learning from his/her experiences (Attwell \& Hughes, 2010; Renon, 2012). Vygotsky's constructivism also influences Attwell's perspective (2007) that 'personal learning environments' is related to technology development. In line with Boyle (1997), there are some learningbased constructivist theories connected with the digital learning environment. As the concept of constructivist theory explains, people are able to understand knowledge by getting the experience on their own. Boyle (1997) illustrated that these circumstances enable students to increase their knowledge through the construction process by taking control to find sources, and resulting in the enhancement of personal awareness. 
PLE may be categorized as technology, involving tools and services in order to provide personal and community-based learning in multiple contexts and resources then fostering autonomy and control of the learners. Personal Learning Environments facilitate both theoretically and technologically to integrate personal learning and to work (Attwell \& Costa, 2009). Attwell (2007) believes that PLE is not a software application. Instead, it belongs to a new methodology that implements technology in the learning process. PLE is determined as a new concept in the digital learning environment that is supported by social media and considered to be an appropriate platform for student learning (Dabbagh \& Kitsantas, 2012).

Moreover, PLE takes into consideration that the process of learning will never run in single learning commitment. In other words, the process must be linked with other circumstances and context (Attwell, 2007). Reinders (2014) emphasizes that the function of PLE for teachers is to encourage the learner development and manage lifelong learning. According to constructivism, the quality of learning will be a more meaningful connection with social communication and active collaboration (Palincsar, 1998). This theory views that the learning environment is encouraged by the teacher's role as a facilitator and motivator for the students rather than a knowledge provider.

The PLE permits the student to expend learning assets, as well as to create them. Taking in this manner develops from being an exchange of substance and learning to the generation of substance and information (Marianos, Ungur, \& Manouselis, 2011). PLEs are winding up being used more broadly by teachers who are reacting to the E-learning requirements of their students (Harwood, 2014).

As facilitators of learning, educators could help PLE students act naturally and pick up the related metacognitive abilities like arranging, sorting out, selfobserving, self-instructing, and self-assessing (Zimmerman, 2000). For instance, as a significant aspect of a metacognitive system, a facilitator could enable students to build up an electronic portfolio. Indeed, the utilization of electronic portfolios has been utilized and upheld as a great way to deal with enabling understudies to manufacture their profile by their expert desires. An electronic portfolio advances the trading of thoughts and input between the maker of the 
portfolio and the individuals who see and interface with it (Lorenzo \& Ittelson, 2005).

Correspondingly, a facilitator could urge students to compose an electronic intelligent diary or blog as a learning space. Williams and Jacob (2005) utilized this approach in one of their business courses, and their quantitative and subjective examination of the gathered information demonstrated that students agreed to the procedures of the utilization of sites to enhance instruction and learning (Williams \& Jacob, 2005).

\section{Blogging as a PLE Medium for University Students}

A blog for most higher education students is not a strange framework anymore for this recent decade. High school students are familiar with blogging for sharing their stories to keep people updated about their news. When they are in university, they may try to share journal articles they read with other readers outside of the classroom. Blogging is trouble-free, easy to use and a free software program that everyone can use and share their ideas on (Dennis, 2015).

By conceptualizing the blog as a medium rather than a sort, it is conceivable to perceive how writers opt more for paper than online journals (Boyd, 2006). It is not the traditions or substance writing that characterize web journals, but the system in which individuals can communicate. Utilizing paper, individuals archive their lives. The same is right in the blog. Utilizing paper, individuals take notes, while another is an online journal.

In order to record a personal life through a blog, two types of blogs according to Hodkinson (2006) and Wei (2004) are allowed, namely personal journal and journal blog. These blogs are different in purpose. Whie the personal journal type describes bloggers' personal experiences and reflections, which is commonly used mostly by females and teenagers, the journal blog represents a forum in which the primary purpose is to communicate with others, share ideas and interests, and have sustainability relationships.

Blogging combines parts of reasoning composition with aspects of the presentation of composing - and it includes discussion too. Blogs or personal weblogs give a chance for individuals to express themselves freely through 
online text and the content tends to be more associated with emotions and feelings than social concern sharing like hobbies or interests (Trammell et al., 2006). Blogging is viewed as a 'performative writing' that hones the skill of writing rather than the appearance or the product (Gregg, 2006). Giddens (1994) stated that the blog is considered a narrative that creates identity about the personal experience of the author. However, Ewins (2005) and Gergen (2000) add that the blog indicates a narrative creation that can be presented through various means to reveal a distinct identity ('multiphrenic' identity).

Also, blogging represents a conversation tool for the writer and the reader through a combination of a writing skill and writing presentation (Larsen \& Hole, 2009). A personal blog is the most frequently used blog that represents one of the social media and platforms to express opinions, emotions, and show the writer's identity (Liu, 2014).

The study conducted by Luo and Hyland (2016) showed that English teachers have an essential role in helping Chinese scientists to accomplish their work for international journals through a comprehensive process involving translating, editing, revising, coping with difficult English words until composing a scientific literature review. This means that although a scientist has high credibility in managing their learning environment, the presence of a teacher still has a particular consideration function as a facilitator rather than a knowledge distributor because they are needed when complicated things come in the form of an English term, not the writing process that they can cope with (Reinders, 2014).

Zheng, Yim \& Warschauer's (2018) study revealed that a standout amongst the most generally talked about affordances of the utilization of internet-based life in composing guidance is the apprenticeship of a study into joint research and composing talk networks, which are common in the most expert and academic settings. Wikis, blogs, and cloud-based composing stages, for example, Google Docs, are models of synergistic composition devices that enable various creators to make rundowns, conceptualize, and assemble comments on catalogs for scholarly research ventures. Such tasks may help cultivate L2 understudies' subject-specific learning, and besides, widen their digital literacy abilities. 
The emergence of technology, which has a significant impact on teaching writing, is also shown in a study conducted by Bloch (2018). Blogging, chatting, emailing, wikis and fan fiction are considered the improvement of a moveable kind affected to enhance literacy mostly beyond the classroom.

Nevado (2016) revealed that the blog is designed in line with an essential aim of Personal Learning Environments, which is that users become producers by creating and sharing and learners become producers and consumers of learning materials simultaneously. Moreover, it takes into account the principles of PLEs, which are the ability to create, to share ideas, to join groups, and to publish content that will be available for other users who will use this material to increment their knowledge. Another critical factor that the participants of the research project took into account in their interventions is that learning takes place in different contexts and a single learning provider will not provide situations and materials. Many individuals will take part in this collaborative learning by adding information and giving their opinion about different topics, experiences, and ideas-in this case, constructing scientific writing.

\section{RESEARCH METHOD}

This research study was analyzed qualitatively using a narrative inquiry design proposed by Barkhuizen, et al. (2014). Narrative inquiry enables both storytelling and research together by using stories as research data or a tool for data analysis. Twenty-eight students participated in this study. The participants were the first semester students of master program students in Indonesia. The participants work individually on a personal learning environment task as learning outside of the classroom. This personal learning environment activity spanned for 16 weeks. The participating students agreed to additional tasks in academic writing for publication class.

The first stage was planning a framework for developing a personal learning environment by reading journal articles and blogging. Lecturers prepared resources that the students could visit and read the journal articles. The next preparation was introducing blogs as a framework for students to write summaries and discuss the content with the readers. The framework was based 
on the idea that students did the activities at the campus library, at the dormitory or home, or in other places that they enjoyed reading and blogging at.

The second stage was conducting the study. The students did the implementation of reading article journals and blogging for 12 weeks. It is suggested that each week they read at least one journal article. The students created their blog address and wrote the content based on their activities on reading and blogging. They discussed the content with the readers who had a similar interest in reading.

The third stage was the lecturer and students had reflected on the activities by having a discussion about the difficulties, challenges, and chances. This discussion would be beneficial both for a lecturer and a student in conducting the lesson and learning Academic Writing for publication. Students gave a response to the questionnaire about the personal learning environment and were interviewed to obtain more data on the issue. The in-depth interviews were audio records that were subsequently transcribed. The blogs, the responses to the questionnaire, and the in-depth interviews were later used as the sources of data. All the participants' written assignments were manually coded. Member and assignments checking, suggested by Merriam (1998) were used to deal with the trustworthiness of the data because the data were exposed to all participants and the lecturer to give commentaries and review.

\section{FINDING AND DISCUSSION}

This part presents three important points about how personal learning environment affects higher education students to work on their academic writing, including the way to encourage students to write academic writing through the personal learning environment as a learning platform, implementing PLEs in the academic writing course seen from content knowledge and pedagogical consideration.

\section{Ways of Encouraging Students to Write Academic Writing through the Personal Learning Environment as a Learning Platform}

The students get challenges to learn academic writing for publication. They get problems not only related to academic writing literacy but also in 
reading journal articles as the necessary skills for writing for publication. Most of all students tried hard to solve the problems. As a result, learning from the lecturer for 16 meetings does not suffice for them. It needs another way to cope with the problem by offering an efficient solution, a personal learning environment to work out in optimizing the students' learning by using educational technology-new usage of the technologies for learning such as instant messaging, file sharing, social networking, blogging, web searching help young people to learn new things (Attwell, 2007).

Rowlands et al., (2008) stated that students are acquiring knowledge not only from reading books and journals, but also for using social media. Using Whatsapp as a message for discussion between the lecturer and friends, file sharing to other students, the use of Youtube for understanding the expert's talks, and Vlog to get the sources, and also web searching is becoming the daily activities of the master degree students. This phenomenon gives power and particular interest to students for having creative ability, sharing ability, joining group ability, and publishing articles. These students' abilities have the potential to bring together and result in interrelated aspects that combine university classroom and out class activities. The activities assist students in becoming autonomous learners. They tried to find ideas and solutions for fulfilling their own needs.

Central to the idea of personal learning environment, tasks were to help them to be autonomous learners (Reinders, 2014). This was attained by using a social medium, in this case, blogging, as the platform to learn new things, read scholarly articles, upload their summary, and discuss with their friends and visitors of their blogs on which they worked further to write their summaries and feedback. The students are given the freedom to choose their material (scholarly articles) then write their summaries and upload to their blog every week.

In the next stage, the students were assigned to provide feedback on their peers' writings. To help the students organize their feedback, the lecturer provided a guideline to ask questions or give responses. One blog was allocated to review or comment on another summary writing. While all students wrote their summary of the scholarly articles in the form of an argumentative essay, 
they wrote the feedback in a short discussion related to the topic. However, some of the students got feedback from professionals that give responses to the summaries.

In this feedback task, a student got another response or comment from a blog visitor. From the interview with the student, he loved to receive the comments. He believed that he learned something new from the discussion with new people who visit his blogs and give a proper response to his summary. As a result, all students wrote a summary of the scholarly articles and got feedback from their friends beyond what their lecturer had demonstrated.

Based on the finding, the students learned academic writing in the classroom for 100 minutes each week. However, they learned academic writing outside the classroom for more than 100 minutes. Seventeen students spent three hours (180 minutes), eight students spent 4 hours (240 minutes), and three students spent five or more hours (at least 300 minutes) to learn academic writing outside the classroom. Most of them did the academic writing task at the dormitory with good Internet access, and the rest did the task at the university library. Time allocated for the students to do the academic writing was not enough-100 minutes; they needed more time to read scholarly articles and do the summary at least twice or quadruple the time needed in the classroom. Personal Learning Environment through blogging can be a way for graduate students to foster and motivate students to learn academic writing (DH Schunk, BJ Zimmerman, 2007).

The academic writing for publication is a complex activity and needs more time to learn linguistically and cognitively. A total of 100 minutes a week for sixteen meetings is not enough for the students. Moreover, most of the students did not have sufficient knowledge of academic writing for publication when they were in the bachelor year. Most of the students read scholarly articles for the first time when they were in the master's year. In academic writing class, students need to have critical reading activities (Fairclough, 2014; Hyland, 2014; McKay, 2016). They need to get the main ideas of the scholarly article they have to read to support their learning. Then, they write a summary of the reading articles to enrich their knowledge of academic writing. That is academic writing becoming a problematic subject for postgraduate students in Indonesia. 
Covering the challenges of having good ability in an academic writing class, it needs the motivation to learn not only in the classroom but also outside the classroom. The finding showed that 24 students have intrinsic motivation to learn academic writing. They research what they need to know about journal websites, and professional websites and only four students depended on the academic writing lecturer. It showed that postgraduate students could have the right personal learning environment by choosing their places, sources, and time to do activities related to academic writing tasks (Hyland, 2015; Richards \& Rodgers, 2014; Richards, 2015).

\section{Implementing PLEs in the Academic Writing Course: Content Knowledge Consideration}

Becoming a learner in the Gen $\mathrm{Z}$ era is complicated. Some universities or colleges are sterile from the use of the Internet due to such a belief that the Internet gives a lousy effect on the young generation. Since the 1950s, the openaccess has given fear to parents and teachers in how to cope with this dreadful technology (Bonk, 2009; Jeffrey \& Troman, 2004). Slowly, time changed the way people thought, and young learners have realized that technologies are changing rapidly, instant message, file sharing, blogging, and social networking have essential roles in their life (Attwell, 2007).

Nowadays, with technology facilities, we can create, share ideas, and join an academic group. In an academic writing class, master students cannot rely only on their lecturers: they need to explore other sources to read and enrich their knowledge of academic writing by finding downloadable open-access materials. Based on the findings from 28 master students, 27 students found supporting materials and read e-books, 20 students read materials from professional websites, and 22 students found and read materials from Google Scholar. The other tools that students use are ELT Podcasts, video/ Youtube channel, online newspapers, email, social media and also sharing documents. Students comprised all the various tools and use in daily life for learning.

Each week the students read a scholarly article related to the research topic that they wanted to choose in the second semester. After reading, the students did a summary of 150 words to grasp the core of the article. On the subsequent day, the students also read the other student's work and give 
responses, comments, and questions. In this process, students learned new knowledge from the article that they read and also the other student's summary. There is an interactive learning process from such a personal learning environment, which allows them to choose their reading materials and the chosen time and place that have possible result in developing the ability of academic writing, critical reading, and the use of technology by blogging. It is in line with Attwell's (2007) idea that the personal learning environment can organize these various areas and inter-relate learning from daily life with learning from the university.

The following were responses from the students in doing blogging for academic writing for publication:

This is the first time I do blogging. By having this activity, I would like to share my writing and get feedback from others to have meaningful learning. (Jose)

Blogging gives a challenge for me and has self-feedback from the interactions and comments from others means it gives an appreciation of what I have done in academic writing. (Rebecca)

Blogging is fun. I have been blogging since 2012. It started when I learned about IELTS and MOOC. Now, I do blogging for academic writing. I feel blogging is reflecting what I have done this semester. (Andrew)

Students' journal summary blog:

\section{Aligning Digital Storytelling to the TPACK Framework: \\ A Learning Experience for Pre-Service Teachers in a Learning-By-Designing Project}

Technology is becoming present in the lives of pre-service teachers. However, the pedagogical use of technology is not inherent to the acquisition of the tool itself. This article described research that explored the role that the TPACK (Technological Pedagogical Content Knowledge) framework had on digital storytelling, a design-based learning opportunity for pre-service teachers taking a technology integration course. This study stressed the importance of viewing technology as a tool to enhance learning. The qualitative method was the adequate choice for the present case study because the perceptions and the constructed meanings of the participants were the focus of the investigative process. The participants in 
the study were composed of a purposive sample; they were 54 pre-service teachers and their instructors at a Southeastern American university attending four sessions of its Introduction to Computers for Teachers course during the Spring Semester of 2010. The primary resources for data collection were interviews with pre-service teachers and the instructor, observations of class activities, surveys, and artifacts analysis. The results indicated that there were gains in the technological pedagogical and content knowledge of the pre-service teachers involved in the research and that they acquired a holistic view of the process of teaching with technology, as a consequence of their participation in the designed digital storytelling project. The use of the TPACK framework during the development of digital storytelling impacted positively the development of the projects created by prospective teachers, benefitting their college teacher education.

Visitor's comment:

June 24, 2018 at 4:06 AM

I saw that you post several times about digital storytelling, do you interest in that topic?

June 24,2018 , at 4:38 AM

Yes, I really do. I am doing my research about digital storytelling project, so yeah I try to find as much as references to enrich my understanding :)

Students' journal summary blog:

13 Juni 2018

TPACK in Elementary and High School Teachers' Self-Reported Classroom Practices with The Interactive Whiteboard (IWB)

The use of interactive whiteboard (IWB) increased in teaching and learning in the classroom. The ways that the teachers incorporate the tool within their teaching practices remain poorly understood. This study examines elementary and high school teachers' self-reported practices with IWB. The conceptual framework centered on teachers' self-reported practices as well 
as Technological Pedagogical Content Knowledge (TPACK). The qualitative design employed in this study. The data collected from discussion groups of 30 teachers. Overall, the results showed a predominance of technological pedagogical knowledge (TPK) and technological knowledge (TK) regardless of grade level, gender, or years of teaching experience.

Visitor's comment:

23 Juni 201822.33

Since the result only shows that TPK and TK that increase, I think we need to do further research in correlation with how to increase other aspects of TPACK, like PK, CK and others. Moreover, we need to analyze the reason why on those two aspects that increase

The fact that blogging was conducted for academic writing made the students fully aware of their ability to construct and share the result of their learning environment activities. This was likely because they were aware that a personal learning environment promoting blogging for academic writing was necessary for their own purposes for getting feedback from the audience and reflection of what they learned to have meaningful learning. Most of the students even remarked that they made many changes because of their blogging activities to construct argument building and share the scholarly articles they read and write the summaries, which encouraged the students to do metacognitive activities, purposely to the content knowledge of their academic writing.

\section{Implementing PLEs in the Academic Writing Course: Pedagogical Consideration}

At the pedagogical level, implementing PLEs requires several mattersmoving towards learner control, monitoring personal learning, assessing learning with PLEs, and encouraging out-of-class learning (Reinders, 2007). These four considerations give an impact and role for teachers and students in balancing the activities both in the classroom and out of a classroom. 
The issue of moving towards learner control is thought provoking, and the most energizing aspect using PLEs with learners is how it gives a reflective outcome on learning and teaching practice. The first action of the teacher/lecturer in running PLE is giving and explaining the rationale to the students so they grasp the aim of doing out-of-classroom activities and the aim of autonomy learning.

Personal Learning Environment actions in out-of-classroom facilitate students to support students' academic writing in the classroom. It is found that 27 students out of 28 always find web-based resources in supporting their academic writing tasks. They tried to find scholarly journals and tips to write a paper from online publication web and professional websites. It showed that students have autonomy learning to solve their problems in academic writing.

The students also asked the lecturer if they thought that they felt that they still had a problem that they could not find a satisfying answer from the website. They wrote in the paper and started to discuss with classmates and lecturers. The following are some students' questions related to academic writing for publication:

How do we make a first impression on the abstract?

Can we submit the same article in more than one publisher at the same time?

About references, what year of articles as resources for our manuscript?

How to choose a good topic for a scholarly article?

There are more than a hundred questions from the students related to academic writing for publication. It showed that the students were curious and wanted to explore more things related to academic writing for publication. As mentioned in the previous paragraph about there being no students who got knowledge about academic writing for publication and based on the data, only one student from 28 got knowledge and practice of argument building. This is a challenge for both students and the lecturer. So, it needs a rationale for students to understand and act in a personal learning environment through blogging in an academic writing class in facilitating and optimizing the students' potential in academic writing (Alsamadani, 2017; Rao \& Torres, 2016). 
That is why the role of the teacher or lecturer in personal learning is essential, as the additional ways of learning, for extra practices and reflection (Borg, 2015). When the students did the summary of the scholarly article and submitted it on their blog, the students needed feedback from the teacher or lecturer. A result of the interview was that most of the students would like to have feedback and comments on what they have done. The feedback on personal learning through blogging in academic writing may happen not only by giving comments on the students' blog but also with any discussion with them directly in the classroom or through chatting using social media. In short, promoting blogging as a personal learning activity gives chances for both teachers and students to have more topic discussions about academic writing.

The personal learning environment supports academic writing for publication classroom activities. They are doing the above activities to give challenges for both teacher/lecturer in conducting PLEs for master students. It gives new roles for teachers to facilitate for different students via monitoring eportfolio through blogging, commenting on the learner's post, giving feedback on students' task on academic writing, and discussing on the problem that the students have in academic writing practice. The teachers' assessment is not only talking about a test score, but the more important thing is that teachers can cultivate the feeling of students' lifelong learning.

As a motivator in PLEs, teachers or lecturers encourage students to engage in out-of-class-learning. They are introducing a collection of tools to learn and it directs students to engage in lifelong learning, including digital tools. Let students practice based on their needs or teachers' requirements to use the tools in doing the tasks. Teachers need to empower the students to use the tools to cultivate the students' potential in learning academic writing. Searching sources on the web, having a critical reading of scholarly articles, summarizing and sharing onto the blog, and giving comments to other students' assignments give positive support and inspiration for the students in academic writing.

\section{CONCLUSION}

Promoting a personal learning environment for emerging academic writing for higher education students can lead to substantial changes in 
learning academic writing for publication. There are some ways of encouraging students to write academic writing through the personal learning environment as a learning platform by searching the sources on the web, using blogging as media to keep and share the materials, and using social media for having a discussion both with teachers and other students. Since they need to learn academic writing for publication, then the necessary foundation of argument building is needed. This will empower the students to have critical thinking and a foundation to build argumentation. Learning in the classroom while being supported by out-of-class learning becomes a key to motivate and cultivate the students' potential to be a lifelong learner to prepare the students to face the future. The other pedagogical consideration in a personal learning environment is reflected by some changes in the teacher's role. Not only do teachers teach but they also have a deeper role as a source, motivator, cultivator, and partner in the students' discussion. The students' roles are learners and producers.[rgt]

\section{REFERENCES}

Alsamadani, H. A. (2018). The effectiveness of using online blogging for students' individual and group writing. International Education Studies, 11, 44-51.

Anderson, J. (2015). Affordance, learning opportunities, and the lesson plan pro forma. ELT Journal, 69, 228-238.

Attwell, G. (2007). Personal learning environments - the future of e-Learning? $E$ Learning Papers, 2. www.elearningpapers.eu

Attwell, G., \& Costa, C. (2009). Integrating personal learning and working environments. Report of the University of Strathclyde Glasgow.

Bloch, J. (2018). Technology for Teaching English as a second language (ESL) Writing. The TESOL Encyclopedia of English Language Teaching, 1-8.

Bonk, C.J. (2009). The world is open: how web technology is revolutionizing education. Jossey-Bass, USA.

Borg, S. (2015). Teacher cognition and language education: Research and practice. Bloomsbury Publishing Plc

Boyd, M. (2012). How we write: Understanding scholarly writing through metaphor, Cambridge University Press, 45, 736-741. 
Boyle, T. (1997). Design for multimedia learning. Upper Saddle River, NJ: Prentice Hall.

Jeffrey, B. ; Troman, G. (2004). Time for ethnography. British Educational Research Journal, 30, 535-548.

Cejudo, M.C.L. (2013). Assessing personal learning environments (PLEs). An expert evaluation. New Approaches in Education Research, 2(1), 39-44

Cheung, Y. L. (2009). First publications in refereed English journals: Difficulties, coping strategies, and recommendations for student training. System 38 (2010) 134-141

Cho, S. (2010). Academic biliteracy challenges: Korean scholars in the United States. Journal of Second Language Writing, 19, 82-94.

Dabbagh, N.,\& Kitsantas, A. (2012). Personal learning environments, social media, and self- regulated learning: A natural formula for connecting formal and informal learning. Internet and Higher Education, 15, 3-8

Dennis, C. A. (2015). Blogging as public pedagogy: creating alternative educational futures. International journal of lifelong education 34(3)

Ewins, R. (2005). Who are you? Weblogs and academic identity. E-Learning 2, no. 4:368-77

Fairclough, N. (1992). Critical language awareness. Routledge.

Franklin, T., \& Harmelen, M.V. (2007). Web 2.0 for content for learning and teaching in Higher Education.

Gergen, K. J. (2000). Qualitative Inquiry: Tensions and transformations. In Denzin, N. K., \& Lincoln, Y. S. (eds). The Handbook of qualitative Research (book chapter). Sage

Giddens, A. (1994). Modernity and self-identity: Self and society in the late modern age. Palo Alto, CA: Stanford University Press.

Gregg, M. (2006). Feeling ordinary: Blogging as a conversational scholarship. Continuum: Journal of Media and Cultural Studies 20(2) 147-60.

Harmelen, M.V. (2008). Design trajectories: four experiments in PLE implementation. Interactive Learning Environments, 16, 35-46.

Harwood, C. (2014). Personal learning environments: using symbalooEDU in learning English for academic purposes. Journal of English for specific purpose at tertiary level, 2(2), 99-215 
Hinkel, E. (2016). Teaching English grammar to speakers of other languages. Routledge

Hodkinson, P. (2006). Subcultural blogging? Online Journals and Group Involvement among UK Goths.

Hyland, K. (2016). Academic publishing and the myth of linguistic injustice. Journal of Second Language Writing, 31, 58-69.

Hyland, K. (2008). Genre and academic writing in the disciplines. Journal of Language Teaching, 41, 543- 562.

Hyland, K. (2016). Teaching and researching writing. Third edition (Applied linguistics in action). Routledge.

Hyland, K. (2014). Activity and evaluation: Reporting practices in academic writing. Academic Discourse: Chapter 6. Taylor \& Francis.

Jaclyn, M., Wells., \& Lars, S. (2018). Preparing graduate students for academic publishing: Results from a study of published rhetoric and composition scholars. Pedagogy, 18, 131-156.

Khan, H.B. (2001). Web-based training. Educational Technology. Educational Technology Publication, Englewood Cliffs, New Jersey.

Kolb, D.A. (2015). Experiential Learning: Experience as the source of learning and Development, second edition. Pearson, USA.

Kuteeva, M., \& Mauranen, A. (2014). Writing for publication in multilingual contexts: An introduction to the special issue. Journal of English for Academic Purposes, 13, 1-4.

Larsen, A. K. and Hole, G. O. (2009). Virtual book: E-pedagogy for teachers in higher education HiB, VIRCLASS production, Bergen, Norway

Lebenicnick, M., Pitt, I., \& Starcic, A., I. (2015). Use of online learning resources in the development of learning environments at the intersection of formal and informal learning: The student as autonomous designer. CEPS Journal, 5, 95113.

Liew, B. T., \& Kang, M. (2012). Personal Learning Environment for Education: A Review and Future Directions. In: Chiu D.K.W., Wang M., Popescu E., Li Q., Lau R. (eds) New Horizons in Web Based Learning. ICWL 2012. Lecture Notes in Computer Science, vol 7697, 30-38

Liu, M.-C., Su, Y.-N., Chen, N.-S. and Huang, Y.-M. (2014). Mobile 2.0 learning: Empowering mobile learning with socialized context sharing. (2014), 511-515. 
Lorenzo, G., \& Ittelson, J. (2005). An overview of e-portfolios.

Luo, N., \& Hyland, K. (2016). Chinese academics writing for publication: English teachers as text mediators. Journal of Second Language Writing, 33, 43-55.

McLoughlin, C., \& Lee, M.J.W. (2010). Personalized and self-regulated learning in the web 2.0 era: International exemplars of innovative pedagogy using social software. Australian Journal of Education Technology, 26, 28-43.

Marianos, N., Ungur, M., \& Manouselis, N. (2011). Evaluating a personal learning environment for digital storytelling. Interaction Design and Architecture(S) Journal - IxD\&A, N. 11-12, 37-50

Merriam, S.B. (1998). Qualitative research and case study applications in education. San Francisco, CA: Jossey-Bass.

Meyer, F.S. (2014). Writing and publishing in peripheral scholarly journals: How to enhance the global influence of multilingual scholars?. Journal of English for Academic Purposes, 13, 78-82.

Nevado, L. A. (2016). How a personal learning environment can help primary English teachers to increase their knowledge. Final degree project Facultat d'Educació Traducció i Ciències Humanes Universitat de Vic-Universitat Central de Catalunya.

Niamika, E., \& Utami, W. (2017). Logical fallacies in Indonesian EFL learners' argumentative writing: Students' perspectives. Dinamika Ilmu, 17, 71-81

Nygaard, L.P. (2015). Publishing and perishing: An academic literacies framework for investigating research productivity. Journal of Studies in Higher Education, 42, 519-532.

Palincsar, A.S. (1998). Social constructivist perspectives on teaching and learning. Annual Review of Psychology, 49, 345-375.

Peng, Jian-E., \& Woodrow, L. (2010). Willingness to communicate in English: A model in the Chinese EFL classroom context. Language Learning: A Journal of Research in Language Studies. (60) 4, 834-876

Pirttimaa, R., Takala, M., \& Ladonlahti, T. (2015). Students in higher education with reading and writing difficulties. Education Inquiry, 6(1)

Rahimi, E., Berg, J.V.D., Veen, W. (2014). Facilitating student-driven constructing of learning environments using Web 2.0 personal learning environment. Journal of Computer \& Education, 81, 235-246. 
Rao, K., \& Torres, C. (2016). Supporting academic and affective learning processes for English language learners with universal design for learning. Wiley online library: Tesol Quarterly, 51, 460-472.

Reinders, H. (2014). Personal learning environments for supporting outof-class language learning. English Teacher Forum, 4, 14-19.

Reinders, H., \& Benson, P. (2017). Research agenda: Language learning beyond the classroom. Journal of Language Teaching, 50, 561-578

Renon, F. (2012). Personal learning environments (PLEs): Ecologies for building student capability for lifelong learning, Carleton University, Ontario, 3-27.

Rowlands, et al., 2008. The Google generation: The information behavior of the researcher of the future. New Information Perspectives, 60, 290-310.

Richards, J.C., \& Rodgers, T.S. (2014). Approaches and Methods in language teaching (Third Edition). Cambridge University Press.

Richard, J.C. (2015). The Changing face of language learning: Learning beyond the classroom. RELC Journal, 46, 5-22.

Samantha, E., Helen H., Chloe A., Kim B., Francesca B., Daisy C., Colin C., Nathan C., Jessica H., Natasha L., Devon N., Oluchi U., Amber R., Gagan-Preet R., Heidi W., \& Philip W. (2018) 'On the outside I'm smiling but inside I'm crying': Communication successes and challenges for undergraduate academic writing. Journal of Further and Higher Education.

Schunk, D.H., \& Zimmerman, B.J. (2006). Influencing children's self-efficacy and self-regulation of reading and writing through modeling. Reading \& Writing Quarterly, 23, 7-25.

Trammell, K. D., \& Ferdig, R. E. (2004). Pedagogical implications of classroom blogging. Academic Exchange Quarterly, 8(4), 60-64.

Wahyudi, R. (2016). Second language literacy practices: a case study of a Chinese student in Australia. TEFLIN Journal, Volume 27, Number 1, January 2016.

Wang., \& Kai-Hui, I. (2018). Long-term Chinese students' transitional experiences in UK higher education: a particular focus on their academic adjustment fostering critical thinking skills through argumentative writing. International Journal of Teaching and Learning in Higher Education, 30, 12-25

Wells, J. M., \& Soderlund, L. (2018). Preparing graduate students for academic publishing: results from a study of published rhetoric and composition scholars. Pedagogy 18(1), 131-156. 
Widyastuti, S. (2018). Fostering critical thinking skills through argumentative writing. Cakrawala Pendidikan. June 2018

Williams, J., \& Jacob, J. (2005). Exploring the use of blogs as learning spaces in the higher education sector. Australasian Journal of Educational Technology, 20(2), 232-247.

Wilson, S., Liber, O., Johnson, M., Beauvoir, P., Sharples, P., \& Milligan, C. (2007). Personal learning environments: Challenging the dominant design of educational systems. Journal of e-Learning and Knowledge Society, 3, 27-38.

Yayli, D., \& Canagarajah, A.S. (2018). The processes behind RA introduction writing among Turkish arts and science scholars. English Language Education book series, 1, 111-128. Springer.

Zhang, Z. V., \& Hyland, K. (2018). Student engagement with teacher and automated feedback on L2 writing. Assessing Writing Journal, 90-102. Elsevier

Zheng, B., Yim, S., \& Warschauer, M. (2018). Social media in the writing classroom and beyond. The TESOL Encyclopedia of English Language Teaching, 1-5.

Zimmerman, B. J. (2000). Attaining self-regulation: A social cognitive perspective. In M. Boekaerts, P. R. Pintrich, \& M. Zeidner (Eds.), Handbook of self-regulation (p.13-39). Academic Press. 